\section{$1 \mathrm{P053}$}

分子動力学計算によるプロテオーム構造分析：タンパ ク質間相互作用モデル化研究

○二木 紀行 ${ }^{1}$ 、白水 美香子 ${ }^{2}$ 、末永 敦 ${ }^{1}$ 、沖本 惠明 ${ }^{1}$ 、成見 哲 1 、找崎 俊一 3 、横山 茂之 2 、泰地 真弘人 1 、小長谷 明彦 1 ( ${ }^{1}$ 理研 GSC ゲノム情報 G、 ${ }^{2}$ 理研 GSC タンパク質 G、 ${ }^{3}$ 理研 計算宇宙物理)

ポストゲノムにおいて多くのタンパク質構造が決定されており、それ を活用する乎段が必要となっている。そこで、特に重要と考えられる タンパク質複合体による相互作用機序の予測のため、我々は MD 計算 を用いた解析方法を確立した。まずは、代表的なシグナル伝達タンパ ク質Rasとそのターゲット (Raf1、RalGDS)のタンパク質間相互作用 について、MD計算および実験により相互に補完して決定した。実際 の結合定数との相関、正常型・変異型タンパク質における時間的構造 変化の違いをMD計算より調べ、アミノ酸の変異による結合能低下 のメカニズムを解明した。最初にRas-Raf1/RalGDS RBD 複合体の モデルの構築を行い、それぞれの正常型 Ras と結合能低下に関わる変 異型 Ras との複合体における変化の違いをMD計算により調查した。 その結果、結合部位の原子間距離に正常体と変異体とで明らかな違い があることがわかった。結合能に関わる重要な残基において、正常体 では水素結合が保たれているのに対し、変異体ではそれが離れてし まっていた。さらに、RMSF およびPCAでは、結合領域において正 常体よりも変異体の方が大きいゆらぎを示した。そして、MM-PBSA による自由エネルギーの比較では、正常体に比べて変翼体の自由エネ ルギーの方が大きいことが確認された。以上の結果から、アミノ酸残 基の変異により、結合部位の構造に垔みが生じることで、結合能が大 きく低下すると結論した。これらの MD シミュレーションで示され た結果は、実験による結果と定性的に一致しており、タンパク質間結 合メカニズムの高精度予測が可能であると示唆している。つまり、タ ンパク質の相互作用解析においては、高精度 MD シミュレーション が有効な手段となり得ることを明らかにした。

N. Futatsugi, M. Shirouzu, A Suenaga, N Okimoto, T Narumi, T. Ebisuzaki, S. Yokoyama, M. Taiji and A. Konagaya: Proteomic Structural Analysis based on Molecular Dynamics Simulations: Protein-Protein Interactions of Ras-Raf and Ras-RalGDS com-

\section{$1 \mathrm{P} 055$}

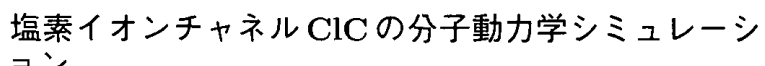

○末永 敦 ${ }^{1}$ 、後藤 邦彦 $2 、 Y e h \mathrm{Jay}^{2}$ 、泰地 真弘人 1 、外山 聡

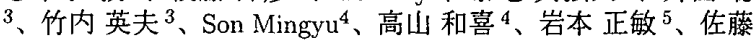
郁郎 ${ }^{6}$ 、楢橋 敏夫 2 、小長谷明彦 ${ }^{1}\left({ }^{1}\right.$ 理研・GSC. ゲ) 情 報、2 ノースウエスタン大·分子薬理、 3 東北大·薬学、 4 東 北大 $\cdot$ 工、 ${ }^{5}$ 東北学院大、 ${ }^{6}$ 宮城県ガンセンター)

塩素イオンチャネル $\mathrm{ClC}$ は真核、有核細胞のすべての細胞に認めら れ、電解質バランスをとっている。筋においては静止膜電位を安定 化させ與奮性を制御しており、電解質ホメオスタシスにおける重要な 酥素である。今回 $\mathrm{ClC}$ チャネルのイオン透過機構を解明するために、 分子動力学シミュレーションを行った。三次構造の決定されているサ

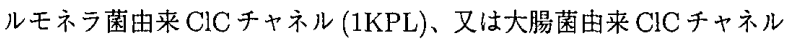
(1KPK) 二量体をリン脂質二重膜に埋め込み、膜内外に $\mathrm{Na}$ イオン、 Cl イオンをそれぞれランダムに配置した。箱型に水を発生させ：周 期境界条件下に扮いて Particle-mesh Ewald 法を用いて、数種初期構 造より 2ナノ秒（計 50 ナノ秒）の計算を行った。初期構造に紌胞内 $\mathrm{Na}$ イオンが存在するときにのみ細胞外にある $\mathrm{Cl}$ イオンは ClCチャネ ルを透過した。細胞内から流出した Naイオンは細胞外の Cl イオン と Cl-Na+-Cl-Na+-Cl-の数珠状の構造（single file）を形成してチャ ネルの局所的コンホメーションの変化を伴って、練胞内に透過した。 細菌において、運動器官である䫒毛は $\mathrm{Na}$ イオンの電気化学的電位を 利用して動いており、Naイオンは運動中練胞内に蓄積すると考えら れ、その箧位を安定化させるために $\mathrm{ClC}$ チャネルは働いていると考 えられる。我々の結果は $\mathrm{ClC}$ チャルは Naイオンによって動く $\mathrm{Na}$ イオン-Cl イオン交換体であることを示唆した。

A. Suenaga, K. Goto, J. Z. Yeh, M. Taiji, A. Toyama, H. Takeuchi, M. Son, K. Takayama, M. Iwamoto, I. Sato, T. Narahashi and A. Konagaya : Molecular dynamics simulation of chloride channel $\mathrm{ClC}$

\section{$1 \mathrm{P} 054$}

\section{タンパク質と水分子の共同運動に関する研究}

○沖本 憲明 1 、中村卓 2 、末永 敦 1 、二木 紀之 1 、平野 秀典 ${ }^{3}$ 、泰地 真弘人 1 、小長谷 明彦 1 、山口勇 ${ }^{2}$ 、戎崎 俊一 ${ }^{3}(1$ 理研· GSC、 ${ }^{2}$ 理研 $\cdot P S C 、{ }^{3}$ 理研 ·和光)

醅素タンパク質は、水溶液中で固有の構造を維持しながら溶媒との熱 的エネルギーのやり取りにより動的に摇らいでいる。この動的な摇ら ぎが、タンパク質の機能発現を引き起こすのである。タンパク質の機 能と構造変化を関連付ける証起は、タンパク質のX線結晶解析研究に より数多く提示されている。これらの研究によれば、リガンド結合状 態とリガンド非結合状態のタンパク質構造の比較は、ドメインや二次 構造を含む大きな構造変化を示している。このことから、タンパク啠 の機能を理解するためには、タンパク質のダイナミクスをより媣く理 解する必要があると言える。更に、酵素のような水溶性タンパク質は 水溶液中でその機能を発現することから、タンパク質-溶媒水の相互 作用は大きく、タンパク質-溶媒間の共同運動を適切に理解すること も重要となる。X線結晶構造は、リガンド結合状態と非結合状態の構 造から構造变化に関する情報を提供してくれるが、タンパク質のダイ ナミクスについては言及できない。このようなタンパク質のタイイナミ クスを理解する場合、分子動力学計算が非常に効果的な道具となる。 そこで、本研究では、分子動力学計算により、水溶性タンパク質のダ イナミクスと溶媒水との共同運動に着目し研究を行った。本研究で は、イネいもち病を引き起こす植物性菌内でメラニン生合成に関連す る酵素の1つであるシタロン脱水素酵素 (SD)（文献 1) を標的タン パクとした。分子動力学計算の結果から、リガンド非結合型はリガン ド結合型よりも大きく摇らいでおり、その摇らぎは溶媒水分子のダイ ナミクスと連動していることがわかった。また、この摇らぎの中で、 リガンド分子を活性部位まで運ぶ通路がタンパク内部に現れることも わかった。

N.Okimoto, T.Nakamura, A.Suenaga, N.Futatsugi, Y.Hirano, M.Taiji, A.Konagaya, I.Yamaguchi and T.Ebisuzaki : Cooperative Motions of Protein and Hydration Water Molecules: Molecular Dynamics Study of Scytalone Dehydratase

\section{$1 \mathrm{P} 056$}

分子動力学シミュレーションによる細菌べん毛繊維の 超らせん構造変化

○北尾彰朗 1 、米倉 功治 2,4 、眞木さ扰り $3,4 、$ Samatey Fadel ${ }^{3}$ 、 今田 勝已 ${ }^{2,3}$ 、難波啓一 2,3 、鄉信広 ${ }^{5,6}$ ( 1 東大·分生研、2 阪 大院·生命機能、 ${ }^{3} \mathrm{JST} \cdot \mathrm{ICORP} \cdot$ 超分子ナノマシン、 ${ }^{4} \mathrm{UCSF} \cdot$ Dept. of Biology、 ${ }^{5}$ 原研、 ${ }^{6}$ 奈良先端大)

細菌べん毛は多種類の蛋白質が集合した生体超分子であり、サル モネラ菌などの細菌の運動を制衔している。推進力を生み出すスク リューにあたる部分は 1 種類の蛋白質 flagellin が会合した織維であ り、超らせん構造を形成している。細菌はべん毛の回転方向の変化に よって超らせん構造を変化させ、運動を制御する。本研究は、X 線結 晶解析と電子顕微鏡によって原子レベルで決定されたべん毛瀻維の 3 次元立体構造 [1-2] に基づいて構築した大規模系（flagellin 44 量体、 溶媒を含めて 240 万原子) の分子動力学シミュレーションによって、 超らせん構造変化のメカニズムを原子レベルで解明することを目指し たものである。

具体的には、まず立体構造決定が終了している右巻き直線型の立体 構造からシミュレーションを開始し、回転力を加えることにより $3 つ$ の超らせん構造、ノーマル、セミコイル、カーリーに対応する原子レ ベルのモデルを準安定な構造として作り出すことに成功した。また、 様々な強さの回転力を加えることによって超らせん構造間を遷移する 様子をシミュレーションで観察することを可能にした。これにより、 マイクロメータの大きさをもつべん毛緎維の超らせん構造変化と個々 の蛋白質の立体構造変化との関係を関係が明らかになりつつある。

文献

[1]F.A.Samatey et al. Nature 410331 (2001). [2] K.Yonekura, et al Nature 424643 (2003)

A.Kitao, K.Yonekura, S.Maki, F.A.Samatey, K.Imada, K.Namba, N.Go : Supercoil transition of bacterial flagellar filament by molecular dynamics simulation 